\title{
The Relationship between Teachers' Job Embeddedness and Vocational Belonging Perceptions
}

\author{
Kaya Yıldız \\ Assoc. Prof., Faculty of Education, Bolu Abant Izzet Baysal University, Bolu, Turkey
}

Copyright $\subseteq 2018$ by authors, all rights reserved. Authors agree that this article remains permanently open access under the terms of the Creative Commons Attribution License 4.0 International License

\begin{abstract}
In this study, the relationship between primary school teachers' perceptions of job embeddedness and vocational belonging was analyzed using the correlational research model. The study group consisted of 258 primary school teachers working at primary schools located in Bolu city center in the 2017 - 2018 academic year. The research data were collected using through two scales: (1) the "Job Embeddedness Scale" originally developed by Mitchell et al. (2001), revised by Felps et al. (2009) and adapted into Turkish by Kiran (2017), and (2) the "Vocational Belonging Scale" developed by Keskin and Pakdemirli (2016). The study was designed as a correlational study in order to analyze the relationship between primary school teachers' job embeddedness and vocational belonging perceptions. The data were analyzed through SPSS for Windows 21 program. For the analysis of the data, the percentage and frequency values, the mean and the standard deviation scores of the scales were calculated. The findings revealed a positive, moderate level relationship between teachers' job embeddedness and vocational belonging perceptions.
\end{abstract}

Keywords Job Embeddedness, Vocational Belonging, Primary School Teacher

\section{Introduction}

Rapidly evolving information and communication technologies have led to substantial changes in the core of individual and social life. The necessity of good education cannot be denied in order to advance as a society and to achieve an improved level of prosperity. Today, great technological developments and consequent sociological changes have made it necessary for all societies to adapt to continuously changing and renewing conditions of the times. Such changes urge societies to communicate and interact more than ever. Such an important social transformation increases the importance of higher order cognitive skills such as effective communication, recognition of diverse cultures, development of collaboration at an advanced level, competition on a global scale and ability to think in a solution-oriented way. In this context, it is necessary to increase the quality of education provided at schools to achieve better outcomes. A rise in success at schools can only be realized with qualified teachers. In other words, it is necessary to have good teachers to educate talented students $[1,2]$. It is necessary for teachers, who are the architects of society, to be trained at a level that can respond to the needs of the country and the era. That is because the prosperity of a country depends on well-trained teachers who have professional and personal qualifications that are sufficient to carry out their responsibilities in the best possible way. That is, the teaching profession is a profession that determines the future of communities - in other words, the fate of communities.

Teachers should be the individuals who can assess the conditions in the best possible way to respond to the rapidly changing needs of the society and educational institutions. They should work continuously to achieve perfection and be able to show flexibility in this path through creativity. They should not have any ideological obsessions that may harm the basic principles of the society. An educational system can attain its objectives only if these specified objectives are achieved at schools and classes that are the subsystems of that educational system. The ability of those classes to reach the specified objectives depends on the activities that are carried out in classrooms. At this point, teachers and their organizational behaviors come to the forefront. The teaching profession is a concept that establishes a position within educational institutions. It also establishes a set of behaviors prescribed by that position. It refers to the status, responsibilities and relationships of that position. Studies on teachers and the teaching profession in the context of organizational behavior actually aim to analyze the organizational behavior of an employee in an educational organization. This study presents an analysis of the behaviors that reflect teachers' perceptions of job embeddedness and vocational belonging. 


\subsection{Job Embeddedness}

Today, several new concepts that are associated with organizations and organizational effectiveness have begun to be discussed and examined in the literature. One of these concepts is the perception of job embeddedness. The concept of job embeddedness was suggested for the first time by Mitchell, Holtom, Lee, Sablynski and Erez [3]. It is related to an employee's organizational fit, organizational links and self-sacrificing behaviors towards the organization where he works. Proposed by Mitchell et al. [3], the Job Embeddedness Theory offers a new perspective which focuses on factors that encourage an employee to stay in an organization and motivate other employees in this direction. The concept of job embeddedness has been proposed to explain how various factors play a role in keeping an employee on the job [4]. The Job Embeddedness or Embeddedness Theory explains why employees stay on a job with a combination of psychological, social and financial factors. These effects are perceived as a network that wraps and surrounds an employee not only in his workplace but also outside his workplace and in his business circle [3, 5]. Job embeddedness offers rich social connections, job fit and personal investment in an organization; in addition to those, it provides employees with the ability to create opportunities to expand and enhance new skills and social ties with others [5, 6]. Critical aspects of job embeddedness are related to employees' connections with other employees and the community, how employees fit in the organization or their community, and finally what they will have to sacrifice if they have to quit their jobs [7]. Job embeddedness offers a variety of effects related to employee retention in the workplace [3]. Job embeddedness is expressed as an effect that arises from the combination of all mechanisms enabling employees to stay in their current organizations [8]. Job embeddedness includes personal links, fit in the community and organization, and how much employees will have to sacrifice in the event of a job change [9, 10]. Job embeddedness is a situation related to the reasons why employees stay in their organizations [11]. Job embeddedness consists of a combination of factors that keep employees in their jobs.

The Job Embeddedness Theory is associated with three dimensions referring to all factors inside or outside a workplace [3]. These include links, fit and sacrifice. These three dimensions are decisive as much as they allow an individual to connect with his organization or society [12]. Links are considered as formal or non-formal connections between an individual and institutions or other persons. Embeddedness refers to the number of channels that offer connections in social, psychological and financial networks that include the physical surroundings and the society where an employee and his family live. It also refers to the friends and groups at the workplace and outside the workplace. The more the number of connections between a person and the network is, the more likely it is that that person bonds with his job or organization [3], and the less likely it is that that person decides to leave his job [13]. Being the first dimension of job embeddedness, links are based on visible connections with the community and organization. Social links cover the degree of relation with close friends and family members, marriage status, having children to care about, hobbies and religious activities and house ownership. Conversely, organizational links include an employee's title, duration of work in the organization, the degree of interaction with colleagues and participation in organizational committees. Organizational links are based on empirical studies $[14,15]$ previously conducted on normative effects $[16,17]$ and kinship obligations [12]. Therefore, individuals have a large number of links at various points of their lives. Separation from their houses or their jobs may require rearrangement of these links or result in terminating some of these links completely [3]. The second dimension of job embeddedness is adaptation. In an organization, an employee's personal values, career objectives and plans should conform to the demands of his current job such as the organizational culture, job knowledge, skills and abilities. Moreover, an employee also considers how much he fits in his society and his environment. A better fit means that the employee feels a stronger bond with an organization professionally and personally. Social factors (e.g. the general culture, climate and life comfort of the place where the individual lives) also play an important role in an individual's job fit. In addition, outdoor activities such as fishing and skiing, recreational activities such as sports, music and drama, and the political and religious environment vary depending on the place of residence. These conformity assessments may be independent of professional or organizational fit. Moving to another place may require a rearrangement of fit. However, even without a new settlement, a new job may subject employees to conditions such as new working hours and different travel conditions that may turn their general conventions upside down [3]. Organizational fit can be described as the chemical harmony between an individual and the organization [12]. Chemistry fit is about how an individual or a group is in interaction and communication, how they determine their goals, how they can work together for common goals. As a result, a better harmony will mean that employees will be more satisfied with their organization, both professionally and personally, and feel more committed. Therefore, individuals who fit in their jobs or organizations are said to be in the society in which they live will not easily quit their jobs [18]. The sacrifice dimension refers to the perceived cost of materials or psychological interests that will be lost if an employee quits his job. For example, leaving an organization may refer to personal losses such as giving up on fellow employees, interesting projects and some side incomes. 
The more an employee gives up when quitting his job, the harder it becomes for him to leave that organization [3]. Moreover, losing a supportive organizational environment should also be considered as a significant cost for employees. Financial (such as higher wages and profits) and psychological (such as organizational support) losses prevent employees from quitting a job [18]. An employee's quitting his job will lead to consequences that may also mean social sacrifices. It may, as well, be difficult to give up a community that is favorable, safe, loved and respected [3].

Earlier studies conducted on job embeddedness have focused mainly on positive results. However, studies conducted later on have suggested that job embeddedness can also lead to negative outcomes such as decrease in motivation and negative workplace behaviors [19]. Burton [20] suggested that employees with an elevated level of job embeddedness are more likely to be exposed to mobbing attacks. According to Sekiguchi, Burton and Sablynski [21], if the level of leader-member exchange and organizational self-esteem is low, a high level of job embeddedness may be detrimental to employee performance. The concept of "embeddedness" is used to describe the effect of limited economic actions and social relations in the academic literature of sociology [21, 22]. Embeddedness is an idea in which the phenomena - which wrap individuals and the events they experience like a network, and which are spread - isolate the individuals even from the most difficult times they experience [3]. Embeddedness addresses not only the effects of specific behaviors, attitudes and intentions at work but also the aspects of social factors that affect behaviors at work [19]. Job embeddedness shows that an employee has several links. These include his social, psychological and financial networks; family; and friends and groups outside the workplace. These links give the employee psychological motivation and empowerment under every condition. Moreover, if anything bad happens, the employee sees and interprets it positively. Thanks to the power and motivation provided by these links. This motivates and advances an individual in whatever he does in his private life and business life. Furthermore, job embeddedness is a more powerful predictor than factors such as job satisfaction and organizational commitment that are the best known and accepted psychological descriptions for organizational outputs such as job continuity, participation and performance [10]. Job embeddedness also helps employees feel a stronger organizational commitment, organizational identification and vocational belonging.

\subsection{Vocational Belonging}

Hagerty and Patusky [23] define the sense of belonging as an individual's valuable participation in and conformity to a community. What is meant by the valuable participation is for an individual to feel to be a valuable and preferred person in a community. The sense of belonging can also be discussed as belonging to a group, as being important for each other, and as a shared common objective and association - which have a meaning that is the opposite of alienation and isolation [23, 24]. Belonging is established with the environment that surrounds an individual. It is shaped and updated and varies by intentional (family, country, ethnicity) or unintentional (education, politics, trade) preferences of an individual. An individual's history of belonging that starts with birth persists in the form of his transferring the characteristics of the environment in which he has lived and grown to his own identity, by means of cognitive, emotional and social learning; the history also persists in the form of his identification and dedifferentiation with that environment despite all the differences the environment has [25]. No matter how it is acquired, belonging has a power of affecting internal dynamics of a society. The sense of belonging becomes indispensable when this power - a part of which an individual belongs to - grows and the opportunities provided by that power increase. Individuals, as a part of the whole, become responsible for their own actions and the formations emerging in that whole, as well as being under the responsibility of other people in that whole. The sense of belonging triggers a mutual responsibility between a person - who belongs to a whole and the whole to which that person belongs in a partnership of power to meet the need for trust [26].

Belonging is a term related to an individual's general attitude towards his profession. Belonging is considered as an attitude resulting from a collection of and a balance of numerous desired and undesired experiences [27]. In this respect, belonging refers to the combination of all the attitudes fed by various aspects of an individual's profession [28]. Many authors have made various definitions of belonging. The concept of vocational belonging was first described by Greenhaus in 1971. In the literature of vocational belonging, the viewpoint that is dominant was offered by Greenhaus as a career-oriented approach. While Greenhaus [29] defines vocational belonging as "the act of a profession's becoming important in an individual's life," Aranya, Pollock and Amernic [30] define vocational belonging as "a relative power by which an individual identifies with a profession." Morrow [29] associates vocational belonging with other types of belonging in his Job Commitment Model and defines vocational belonging as the "career commitment" [31]. An individual's attitudes towards his profession gain importance as a common point in defining this concept. Vocational belonging is associated with many factors, including managers' attitudes and behaviors towards employees in an institution. The factors include not only the way employees get organized for the business life and the level of communication they have but also the extent to which social and economic expectations from the job are fulfilled as well as the qualifications the workplace has. 
Employees' positive ideas on such issues mean that they identify themselves with their institution. This feeds their feelings of vocational belonging, which ensures a high work motivation and an improvement of work efficiency. Thus, vocational belonging is a significant element that determines employees' attitudes and behaviors towards the business life and affects their work performance positively [32]. The common point in the definitions of vocational belonging is the sense of interest and belonging that employees feel towards their profession.

Professions have vital functions for both individuals and the society. They have a decisive role in the functioning of a society, in the determination of an individual's social position and in his participation in the society [33]. According to Karaca [34], belonging to a group and class and being in solidarity with that group or class bring confidence to an employee and prevent the employee from isolation, desperation and loneliness. In societies in which the concept of profession - especially the teaching profession - is very important, the members of the profession feel a need for social support. Social support refers to satisfying an individual's basic needs - such as love, appreciation and self-realization, which are some of the needs in the hierarchy of needs - by means of interactions established with other individuals such as his friends, his family, his superiors or professional advisors [35].

Vocational belonging affects individuals' quality of life, since it is an important part of individuals' professional lives [36]. In other words, vocational belonging is directly associated with individuals' quality of life and directly affects their vocational satisfaction. Vocational belonging directly affects work performance [9]. An employee, who does not feel a sense of belonging towards his profession, may make mistakes and this leads to deterioration of quality of his work. Vocational belonging is of utmost importance in terms of motivating an employee. An individual's vocational belonging may improve his commitment to work and may directly affect his work performance. In other words, a person's job satisfaction and efficiency may improve if he is motivated to work [37]. Vocational belonging is associated with significant outcomes such as improving job performance [9], reducing the dropout rate, and increasing satisfaction at the organizational and professional level [38]. A high level of vocational belonging is associated with positive behaviors that are beneficial for the organization. Accordingly, individuals with high vocational belonging tend to engage in fewer activities harmful to their company [39].

Even though there are many studies available in the literature on job embeddedness, there are a limited number of educational studies or studies on teachers involving job embeddedness. In a study conducted by Lev and Koslowsky [40], the relationship between the job embeddedness of teachers and their organizational citizenship and organizational commitment was examined.
In their study, Lev and Koslowsky [40] examined the relationship between the job embeddedness of teachers and their sense of responsibility, job performance and contextual performance. In the meantime, Burke [41] analyzed the relationship between the job embeddedness of teachers and the support provided by the management or their colleagues. In a study conducted on public officials, Kuran [5] included teachers to the research sample and analyzed the relationship between the job embeddedness of teachers and their organizational cynicism, psychological capital and desire to quit the job. In the literature, there are also studies examining the relationship between the job embeddedness of academicians and their performance and burnout [42], organizational cynicism and work performance [43] in educational institutions. There are studies on job embeddedness in different institutions, as well $[3,8,19,21,44,45,46,47]$. When the literature is reviewed, even though the literature presents more studies conducted on belonging and the rate of studies carried out on belonging especially in educational institutions is remarkable [48], the literature presents a limited number of studies on vocational belonging [49, $5051,52,53,25]$. In other words, there are no studies in the literature that examine the relationship between job embeddedness and vocational belonging directly or indirectly.

It is not possible to achieve the targeted educational outcomes - regardless of how well educational objectives are set and regardless of how functionally the course content is selected and organized - unless those objectives are implemented by teachers who have such objectives and such a comprehension [54]. It has been suggested that the vocational belonging of teachers towards their organizations is of utmost importance in whether educational organizations reach their objectives. Job embeddedness is a significant determinant of the formation of this sense of belonging. It is considered to be important to determine how teachers perceive job embeddedness and vocational belonging especially in primary schools as they are the key point of the educational system. It is also important to reveal whether these perceptions are interrelated or not. The aim of this study, in this context, was to determine the relationship between the behaviors of primary school teachers reflecting their job embeddedness and vocational belonging.

\section{Materials and Methods}

\subsection{Research Design}

Correlational research model was used in the present study to analyze the relationship between primary school teachers' job embeddedness and vocational belonging perceptions as correlation studies not only allow analysis of the relationship between two or more variables without interfering these variables in any way but also are effective 
in revealing relationship between variables and determination of levels of these relationships, they provide necessary clues for future and further studies on these relationships [55].

\subsection{Study Group}

Primary school teachers $(\mathrm{n}=258)$ working at primary schools located in the city center of Bolu - Turkey in the 2017-2018 academic year formed the study group of the present study (see Table 1).

Table 1. Demographic characteristics of the teachers who participate to the study

\begin{tabular}{|c|c|c|c|}
\hline & & $f$ & $\%$ \\
\hline \multirow{2}{*}{ Gender } & Female & 181 & 62,8 \\
\hline & Male & 77 & 37,2 \\
\hline \multirow{6}{*}{ Age } & $25-30$ age range & 22 & 8,6 \\
\hline & $31-35$ age range & 45 & 17,4 \\
\hline & $36-40$ age range & 41 & 15,9 \\
\hline & $41-45$ age range & 70 & 27,1 \\
\hline & $46-50$ age range & 55 & 21,3 \\
\hline & $51+$ age range & 25 & 9,7 \\
\hline \multirow{6}{*}{$\begin{array}{c}\text { Teaching Experience } \\
\text { (years) }\end{array}$} & $1-5$ years & 15 & 5,8 \\
\hline & $6-10$ years & 30 & 11,6 \\
\hline & 11-15 years & 51 & 19,8 \\
\hline & $16-20$ years & 65 & 25,2 \\
\hline & 21-25 years & 72 & 27,9 \\
\hline & $26+$ years & 25 & 9,7 \\
\hline \multicolumn{2}{|c|}{ TOTAL } & 258 & 100,0 \\
\hline
\end{tabular}

When the primary school teachers are examined in terms of their demographic characteristics, as presented in Table 1 , it is seen that while $62.8 \%(\mathrm{n}=181)$ of teachers were female, $37.2 \%(\mathrm{n}=77)$ of them were male. When their ages are concerned, it is observed that even though $27.1 \%(\mathrm{n}=70)$ were between "41-45 age" group, $8.6 \%(\mathrm{n}=22)$ were between "25-30 age" group. When teachers are examined in terms of teaching experience, it is seen that while $27.9 \%$ $(\mathrm{n}=72)$ of them had "21-25 years" of experience in teaching, $9.7 \%(\mathrm{n}=25)$ of them had " $26+$ years" of experience.

\subsection{Collection of Data}

Research data were collected through using "Job Embeddedness Scale" developed initially by Mitchell, Holtom, Lee, Sablynski and Erez [3], then organized by Felps, Mitchell, Hekman, Lee, Holtom and Harman [56], and adapted into Turkish language by Kıran [5] and using "Vocational Belonging Scale" developed by Keskin and Pakdemirli [25]. During the administration of the scales, the following steps were followed: The literature was reviewed to choose the most suitable measurement tool for the purpose of the study. The permission was taken from the authors to use the scales in the study. Then the scales were administered at schools by giving to the primary school teachers by the researcher. During the administration of the scales, the teachers were informed generally about scales, about the aim of the study and voluntarily participation of the teachers was taken as base during this stage. In the 2017 - 2018 academic year, 385 teachers were working at 34 primary schools within the city center of Bolu. During the administration of the scales, the researcher, himself, distributed scales to teachers who participated in the study voluntarily and who were working at these primary schools. Additionally, the researcher, himself, collected the scales in the present study. For the analysis of the data collected, a total of 258 scales were subjected to the analysis processes in the study as 127 scales were not included in the analysis process due to various reasons (e.g. they were blank, with missing markings, and more than one marking scales etc.) and that formed $85.2 \%$ of teachers.

\subsection{Data Collection Tools}

Job Embeddedness Scale: Developed firstly by Mitchell et al. [3], then rearranged and developed by Felps et al. [56], this scale was adapted into Turkish by Kiran [5]. Kıran [5] initially applied exploratory factor analysis on "Job Embeddedness Scale" to determine whether the scale provided theoretical validity. Before applying exploratory factor analysis, skewness and kurtosis of variables included in the job embeddedness scale were checked, no expressions were found with a value higher than absolute value, 2. At adaptation stage of job embeddedness scale, consisting of 6 sub-dimensions determined in Felps et al. [56] study, Kıran [5] applied exploratory factor analysis to understand whether the scale provided structural validity, and expressions in the scale were collected in 5 groups. Kiran [5] first performed an exploratory factor analysis in order to find out whether the job embeddedness scale had theoretical validity. Before the exploratory factor analysis was performed, the skewness and kurtosis of the variables included in the job embeddedness scale were examined. None of the skewness or kurtosis values was greater than 2 . As a result of confirmatory factor analysis of the job embeddedness scale performed by Kiran, the compliance statistics of the model [CMIN=245,701, $d f=77, C M I N / d f=$ 3,191 ( $p=, 0001$ ), GFI=0,921, $C F I=0,937, R M S E A=0,074$, $R M R=0,074)]$ and the goodness of fit indices of the $C F A$ model were found satisfactory. The model's AVE values of the community fit, organizational fit, community links, organizational links, and organizational sacrifice were $.60, .54, .63, .64$ and .41 , respectively. The $\mathrm{CR}$ values of the same variables were $.85, .82, .70, .83$ and .57 , respectively. These values were all satisfactory. As a result of factor analysis, since Item 14 and Item 15 had low levels of factor loads, they were removed from the analysis, and the scale was subjected to analysis again. As a result of factor analysis, the items were collected in 5 dimensions. It was seen that there were no items included in "dedication to environment" dimension. The scale was prepared in 5-point Likert-type and consisted of 16 items and 5 subscales. Among dimensions of the scale, there are 4 items in environmental fit sub-dimension; 4 items in 
organizational fit sub-dimension; 3 items in environmental link sub-dimension; 2 items in organizational sacrifice sub-dimension; 4 items in organizational link sub-dimension. According to results of reliability analyses applied for each sub-dimension, it was concluded as reliable with "environmental fit" dimension as 0.85 , "organizational fit" 0.79 , “organizational link" 0.82 , "environmental link" 0.64, "organizational sacrifice" 0.71 [5]. Also, in this study, the Cronbach Alpha coefficient was found as 0.88 in total for Job Embeddedness Scale. Cronbach's Alpha coefficient for Job Embeddedness Scale sub-dimensions was found as 0.90 for "environmental fit" dimension; 0.91 "organizational fit" dimension, 0.83 for "organizational link" dimension, 0.78 for "environmental link" dimension and 0.82 for "organizational sacrifice" dimension. These findings indicate that measurement tool is reliable [57]. During the analysis of the data collected through Job Embeddedness Scale, Confirmatory Factor Analysis was not performed as Job Embeddedness Scale was used by the researchers in different studies [40, 41, 5] in which teachers were taken as the sample or study group of these studies.

Vocational Belonging Scale: It is a scale consisting of 39 items and 3 dimensions that was prepared in 5-point Likert-type developed by Keskin and Pakdemirli [25]. At the stage of scale development, validity and reliability of the scale were analyzed, and scale reliability was tested with Cronbach-Alpha. It was deemed appropriate to bring together many questions which are related with each other and obtain fewer numbers of consistent questions, and to apply factor analysis to name factors more easily. As a result of Exploratory Factor Analysis, 39 variables were reduced to three factors, and three sub-dimensions were obtained. Factors' Eigen values were 13.1 for factor $1 ; 5.7$ for factor 2; 2.2 for factor 3. Factor 1 explains 26.14 of the total variance; factor 2 explains $20.13 \%$ of the total variance; factor 3 explains $7.55 \%$ of the total variance. These three factors explain $53.81 \%$ of the total variance. As a result of factor analysis, the scale was collected in 3 dimensions. The scale was prepared in 5-point Likert-type and consisted of 39 items and 3 subscales. Among dimensions of the scale, there are 18 items in vocational management belonging, 16 items in vocational organization belonging, and 5 items in vocational place belonging. According to the results of reliability analyses conducted for each sub-dimension, it was concluded that "vocational management belonging" is reliable with 0.95 value; "vocational organization belonging" with 0.90 value; and "vocational place belonging" with 0.76 values [25]. Also in this study, the Cronbach Alpha coefficient was found as .95 in total for Vocational Belonging Scale. Cronbach Alpha coefficient related to Vocational Belonging Scale sub-dimensions were found as .93 for "vocational management belonging", .94 for "vocational organization belonging" and .91 for "vocational place belonging" dimensions. These findings indicate that measurement tool is reliable [57]. During the analysis of the data collected through Vocational Belonging Scale, Confirmatory Factor Analysis was not performed as Vocational Belonging Scale was used by the researchers in different studies $[59,53,49,66]$ in which teachers were taken as the sample or study group of these studies.

\subsection{Data Analysis}

During the analysis of the data, normality distributions of the scales and their sub-dimensions were examined primarily to determine the statistical methods to be used in the analysis of the data obtained from the scales. Skewness and kurtosis of the scales and their sub-dimensions varied between -.360 and 268 depending on the variables in the scales. Skewness and kurtosis values between -1 and +1 indicate that the scales and their sub-dimensions did not significantly deviate from the normal distribution [58]. Based on the results that were obtained, the statistical methods based on the assumption of normal distribution were used.

For the analysis of the data concerning teachers' characteristics, the percentage and frequency values were calculated as well as the mean and the standard deviation scores of the scales. Additionally, an independent samples t-test was used to determine the differences on the scores of the two scales according to gender and two ANOVA analyses were used to determine the differences on the scores of the two scales according to age and teaching experience. The correlation analysis technique was used to examine the relationship between job embeddedness and vocational belonging perceptions of the teachers in this regard. In the meantime, the direction and magnitude of the correlation between pairs of variables were used to determine the nature of the relationships. The absolute values of coefficients between .70 and 1.00 were interpreted as a high level of correlation; those between .69 and .30 as a moderate level of correlation; those that were .29 or below as a low level of correlation; and those with a value closer to .00 were interpreted as having no relationship [55]. The statistical analysis of data was carried out in the SPSS software. The significance was tested at the $\mathrm{p}<.05$ level. When interpreting the mean values, the scores obtained from the scales referred to the following meanings: "1.00-1.80: None," "1.81-2.61: Low," "2.62-3.42: Moderate," "3.4-4.23: High," and "4.24-5.00: Very High."

\section{Findings}

The findings related to teachers' Job Embeddedness and Vocational Belonging perceptions were given in Table 2 and 3 .

\subsection{Teachers' Perceptions of Job Embeddedness}

The findings related to teachers' job embeddedness perceptions are given in Table 2 . 
Table 2. Teachers' job embeddedness perceptions

\begin{tabular}{|c|c|c|c|}
\hline Job Embeddedness & f & $\bar{X}$ & sd \\
\hline Job Embeddedness Scale (Total) & 258 & 3,17 &, 66 \\
\hline Sub-Dimensions & 258 & 3,17 &, 77 \\
\hline Fit - community & 258 & 3,34 &, 78 \\
\hline Fit - organization & 258 & 3,37 &, 87 \\
\hline Links - organization & 258 & 2,92 &, 89 \\
\hline Links - community & 258 & 3,04 &, 91 \\
\hline Sacrifice- organization
\end{tabular}

When Table 2 is examined, it is seen that teachers' job embeddedness perceptions are at $(\bar{X}=3.17, \mathrm{sd}=.66)$ "moderate" level in general. Among sub-dimensions of job embeddedness scale, perceptions of environmental fit dimension $(\bar{X}=3.17$, ss $=.77)$, organizational fit dimension $(\bar{X}=3.34, \mathrm{sd}=.78)$, organizational link dimension $(\bar{X}$ $=3.37, \mathrm{sd}=.87)$, environmental link dimension $(\bar{X}=2.92$, $\mathrm{sd}=.89)$ and organizational sacrifice dimension $(\bar{X}=3.04$, $\mathrm{sd}=.91$ ) are at "moderate" level. When teachers' job embeddedness perceptions are concerned, it is observed that while the highest mean score was found in Organizational Link dimension, the lowest mean score was in Environmental link dimension.

\subsection{Teachers' Perceptions of Vocational Belonging}

The findings related to teachers' Vocational belonging are given in Table 3 .

Table 3. Teachers' perceptions of Vocational Belonging

\begin{tabular}{|c|c|c|c|}
\hline Vocational Belonging & f & $\bar{X}$ & sd \\
\hline Vocational Belonging Scale (Total) & 258 & 2,98 & 1,03 \\
\hline Sub-Dimensions & 258 & 2,82 & 1,07 \\
\hline Vocational Management Belonging & 258 & 3,20 & 1,09 \\
\hline Vocational Organization Belonging & 258 & 2,91 &, 95 \\
\hline Vocational Place Belonging
\end{tabular}

When the mean and standard deviation scores related to teachers' vocational belonging perceptions are examined, as in Table 3, in general, teachers' job belonging perceptions were at $(\bar{X}=2.98, \mathrm{sd}=1.03)$ "moderate" level.
Also, moderate levels of teachers' perceptions were found when teachers' perceptions about the sub-dimensions of the scales ,namely; vocational management belonging dimension ( $\bar{X}=2.82$, sd=1.07), vocational organization belonging dimension $(\bar{X}=3.20, \mathrm{sd}=1.09)$ and vocational place belonging dimension ( $\bar{X}=2.91, \mathrm{sd}=.95$ ) were concerned, When teachers' vocational belonging perceptions are examined, it is observed that while the highest mean score was found in vocational organization belonging dimension, the lowest mean score was found in vocational management belonging dimension.

\subsection{Examining Teachers' Job Embeddedness and Vocational Belonging Perceptions With Respect To Variables}

The findings related to teachers' job embeddedness and vocational belonging perceptions with respect to variables (gender, age, teaching experience) are presented in Table 4, 5,6 .

Table 4. The differences on the scores of teachers' job embeddedness and vocational belonging perceptions with respect to their gender

\begin{tabular}{|c|c|c|c|c|c|c|c|}
\hline \multirow{2}{*}{$\begin{array}{c}\text { Job } \\
\text { Embeddedness } \\
\text { (Total) }\end{array}$} & Gender & $\mathbf{N}$ & $\overline{\mathbf{X}}$ & $\mathbf{s d}$ & $\mathbf{d f}$ & $\mathbf{t}$ & $\mathbf{p}$ \\
\cline { 2 - 8 } & Female & 181 & 3,15 &, 66 & \multirow{2}{*}{256} & \multirow{2}{*}{424} &, 672 \\
\cline { 2 - 8 } & Male & 77 & 3,20 &, 69 & & & $\mathbf{1}$ \\
\hline \multirow{2}{*}{$\begin{array}{c}\text { Vocational } \\
\text { Belonging } \\
\text { (Total) }\end{array}$} & Gender & $\mathbf{N}$ & $\overline{\mathbf{X}}$ & $\mathbf{s d}$ & $\mathbf{d f}$ & $\mathbf{t}$ & $\mathbf{p}$ \\
\cline { 2 - 8 } & Female & 181 & 2,90 & 1,01 & \multirow{2}{*}{256} &, 805 &, 486 \\
\cline { 2 - 6 } & Male & 77 & 3,06 & 1,05 & & & \\
\hline
\end{tabular}

Results of independent samples t-test analysis in Table 4 indicated no significant gender differences on the scores of teachers' job embeddedness ( $\left.\mathrm{t}_{0,05: 256}=.424, \mathrm{p}>.05\right)$ and vocational belonging $\left(\mathrm{t}_{0,05: 256}=.805, \mathrm{p}>.05\right)$ perceptions. However, the male teachers' mean scores were greater than those of the female teachers.

According to ANOVA test, no significant age differences were found, as in Table 5 , on the scores of teachers' job embeddedness $\left(\mathrm{F}_{(6-251)}=.266, \mathrm{p}>05\right)$ and vocational belonging $\left(\mathrm{F}_{(6-251)}=.185, \mathrm{p}>05\right)$ perceptions.

Table 5. The differences on the scores of teachers' job embeddedness and vocational belonging perceptions with respect to their age

\begin{tabular}{|c|c|c|c|c|c|c|c|}
\hline & Age & $\mathbf{N}$ & $\overline{\mathbf{X}}$ & sd & df & $\mathbf{F}$ & $\mathbf{p}$ \\
\hline \multirow{7}{*}{$\begin{array}{c}\text { Job Embeddedness } \\
\text { (Total) }\end{array}$} & 1. $25-30$ age range & 22 & 3,15 &, 65 & \multirow{7}{*}{$\begin{array}{c}6 \\
251\end{array}$} & \multirow{7}{*}{2,634} & \multirow{7}{*}{,266 } \\
\hline & 2. $31-35$ age range & 45 & 3,12 & ,67 & & & \\
\hline & $36-40$ age range & 41 & 3,17 & ,69 & & & \\
\hline & 41-45 age range & 70 & 3,19 &, 70 & & & \\
\hline & 46-50 age range & 55 & 3,18 & ,66 & & & \\
\hline & 6. $51+$ age range & 25 & 3,20 & ,68 & & & \\
\hline & Total & 258 & 3,17 & ,66 & & & \\
\hline \multirow{7}{*}{$\begin{array}{l}\text { Vocational Belonging } \\
\text { (Total) }\end{array}$} & $25-30$ age range & 22 & 2,90 &, 98 & \multirow{7}{*}{$\begin{array}{c}6 \\
251\end{array}$} & \multirow{7}{*}{1,597} & \multirow{7}{*}{, 185} \\
\hline & $31-35$ age range & 45 & 2,95 & ,99 & & & \\
\hline & $36-40$ age range & 41 & 3,01 & 1,01 & & & \\
\hline & 10. $41-45$ age range & 70 & 3,05 & ,99 & & & \\
\hline & 11. 46-50 age range & 55 & 3,01 & 1,02 & & & \\
\hline & 12. $51+$ age range & 25 & 2,98 & 1,05 & & & \\
\hline & Total & 258 & 2,98 & 1,03 & & & \\
\hline
\end{tabular}


Table 6. The differences on the scores of teachers' job embeddedness and vocational belonging perceptions with respect to their teaching experience

\begin{tabular}{|c|c|c|c|c|c|c|c|}
\hline & $\begin{array}{c}\text { Teaching Experience } \\
\text { (years) }\end{array}$ & $\mathbf{N}$ & $\overline{\mathbf{X}}$ & sd & df & $\mathbf{F}$ & $\mathbf{p}$ \\
\hline \multirow{7}{*}{$\begin{array}{c}\text { Job Embeddedness } \\
\text { (Total) }\end{array}$} & 1. $1-5$ years & 15 & 3,14 & ,65 & \multirow{6}{*}{$\begin{array}{c}6 \\
251\end{array}$} & \multirow{7}{*}{5,421} & \multirow{7}{*}{, 199 } \\
\hline & 2. 6-10 years & 30 & 3,11 & 67 & & & \\
\hline & $11-15$ years & 51 & 3,18 & 69 & & & \\
\hline & 4. $16-20$ years & 65 & 3,20 &, 70 & & & \\
\hline & 5. $21-25$ years & 72 & 3,21 & ,66 & & & \\
\hline & 6. $26+$ years & 25 & 3,17 & ,68 & & & \\
\hline & Total & 258 & 3,18 & ,66 & 257 & & \\
\hline \multirow{7}{*}{$\begin{array}{l}\text { Vocational Belonging } \\
\text { (Total) }\end{array}$} & 1. $1-5$ years & 15 & 2,95 & ,98 & \multirow{6}{*}{$\begin{array}{c}6 \\
251\end{array}$} & \multirow{7}{*}{2,368} & \multirow{7}{*}{,241 } \\
\hline & 2. 6-10 years & 30 & 2,90 & ,99 & & & \\
\hline & $11-15$ years & 51 & 3,05 & 1,01 & & & \\
\hline & 4. $16-20$ years & 65 & 3,01 & ,99 & & & \\
\hline & $21-25$ years & 72 & 3,00 & 1,02 & & & \\
\hline & 6. $26+$ years & 25 & 2,98 & 1,05 & & & \\
\hline & Total & 258 & 2,98 & 1,03 & 257 & & \\
\hline
\end{tabular}

Table 7. Relationship between teachers' job embeddedness and vocational belonging perceptions

\begin{tabular}{|ll|c|c|c|c|c|c|c|c|c|c|}
\hline & & $\mathbf{1}$ & $\mathbf{2}$ & $\mathbf{3}$ & $\mathbf{4}$ & $\mathbf{5}$ & $\mathbf{6}$ & $\mathbf{7}$ & $\mathbf{8}$ & $\mathbf{9}$ & $\mathbf{1 0}$ \\
\hline $\mathbf{1 .}$ & Fit - community & 1 & & & & & & & & \\
\hline 2. & Fit - organization & $.42^{* *}$ & 1 & & & & & & & & \\
\hline 3. & Links - organization & $.57^{* *}$ & $.74^{* *}$ & 1 & & & & & & & \\
\hline 4. & Links - community & $.62^{* *}$ & $.45^{* *}$ & $.56^{* *}$ & 1 & & & & & & \\
\hline 5. & Sacrifice - organization & $.43^{* *}$ & $.55^{* *}$ & $.35^{* *}$ & $.47^{* *}$ & 1 & & & & & \\
\hline 6. & Job Embeddedness Scale & $.78^{* *}$ & $.62^{* *}$ & $.81^{* *}$ & $.75^{* *}$ & $.62^{* *}$ & 1 & & & & \\
\hline 7. & Vocational Management & $.30^{*}$ & $.59^{*}$ & $.55^{*}$ & $.29^{*}$ & $.45^{*}$ & $.49^{*}$ & 1 & & & \\
\hline 8. & Vocational Organization & $.37^{*}$ & $.55^{*}$ & $.52^{*}$ & $.25^{*}$ & $.40^{*}$ & $.40^{*}$ & $.73^{* *}$ & 1 & & \\
\hline 9. & Vocational Place & $.35^{*}$ & $.40^{*}$ & $.35^{*}$ & $.30^{*}$ & $.31^{*}$ & $.46^{*}$ & $.78^{* *}$ & $.86^{* *}$ & 1 & \\
\hline 10. & Vocational Belonging Scale & $.32^{*}$ & $.41^{*}$ & $.40^{*}$ & $.32^{*}$ & $.35^{*}$ & $.45^{*}$ & $.80^{* *}$ & $.87^{* *}$ & $.86^{* *}$ & 1 \\
\hline
\end{tabular}

The results of the ANOVA test revealed no significant differences on the scores of teachers' job embeddedness $\left(\mathrm{F}_{(6-251)}=.199, \mathrm{p}>05\right)$ and vocational belonging $\left(\mathrm{F}_{(6-251)}\right.$ $=.241, \mathrm{p}>05)$ perceptions when their years of experience in teaching is concerned as in Table 6.

\subsection{The Relationship between Teachers' Job Embeddedness and Vocational Belonging Perceptions}

The findings related to teachers' job embeddedness and vocational belonging perceptions are given in Table 7 .

Analyzing the Table 7, it can be seen that there is a moderate level positive relationship between teachers' job embeddedness and vocational belonging $(r=0.45 ; \mathrm{p}<0.05)$. As teachers' perceptions of job embeddedness increase, their perceptions of vocational belonging also increase.

\section{Discussion and Conclusions}

In this study, the relationship between job embeddedness and vocational belonging perceptions of elementary school teachers were analyzed. It was found that the teachers' perceptions of job embeddedness were at a moderate level. From among the sub-dimensions of the job embeddedness scale, the environmental fit, organizational fit, organizational connection, environmental connection and organizational sacrifice dimensions were at moderate levels. Based on the analysis of the means and standard deviations related to the job embeddedness, the highest mean score was of the organizational connection 
dimension, while the lowest mean score was of the environmental connection dimension. In the literature, there are studies on job embeddedness in various sectors. Kiran [5] showed that teachers had a high level of job embeddedness perception. Akgündüz, Güzel and Harman [61] also found high levels of perceptions of job embeddedness in their studies on different business sectors, whereas Kesen and Akyüz [62] and Dedeoğlu, Özdevecioğlu and Oflazer [63] found a moderate level of perceptions of job embeddedness among employees.

Job embeddedness is associated with employees' organizational fit, organizational links, and their sacrifices for the organization. Moreover, it refers to all the situations revealed by the employees' connections with social, political and cultural communities in their environment; their relationships with other organizations; their conformity to neighbors, friends, groups and activities; and their links and sacrifices. Critical aspects of job embeddedness are related to employees' connections with other employees and the community, how employees conform to the organization or their community, and finally what they can sacrifice if they have to quit their jobs [7]. Individuals may continue their current job by sacrificing desires arising from themselves or their environment. Based on this framework, Mitchell [3] has addressed two types of job embeddedness: on-the-job embeddedness and off-the-job embeddedness. While on-the-job embeddedness is associated with an individual's internal forces ensuring the employee's stay on the job, off-the-job embeddedness is associated with the individual's private experiences and the forces in the social environment of the individual [44]. Job embeddedness is considered as a critical factor for organizations and individuals. That is because employees with job embeddedness are expected to work harder within the scope of their organizational roles, fulfill their jobs more carefully, exhibit more positive attitudes in general and increase their job performances [60].

In this study, it was concluded that the teachers' perceptions of vocational belonging were at a moderate level. Moreover, from among the sub-dimensions of vocational belonging scale, the vocational management belonging, vocational organization belonging, and vocational place belonging dimensions were at moderate levels. Based on the analysis of the means and standard deviations related to the vocational belonging, the highest mean score was of the vocational organization belonging dimension, while the lowest mean score was of the vocational management belonging dimension. There are several studies in the literature that have been carried out on job embeddedness in educational institutions $[40,41,5]$. There are a limited number of studies in the literature on teachers' perceptions of vocational belonging. Perie and Baker [59], Şahin [53] and Öztaş [49] also found that teachers' perceptions of vocational belonging were at a moderate level. These findings parallel the results of the present research study. In a study conducted on a different business industry by Erdoğan [66], it was concluded that participants' perceptions of vocational belonging were at a high level.

Vocational belonging is associated with employees' various attitudes and behaviors related to their job and covers objectives related to their profession; therefore, vocational belonging is one of the crucial elements that affect individuals' behaviors [39]. At the same time, the professional degree of belonging varies from person to person. Individuals with a high level of vocational belonging are characterized as having a powerful belief in and acceptance of the objectives of a profession, and as eager to make an effort on behalf of their profession and maintain their membership in the profession [64]. Vocational belonging refers to individuals' interests in their profession. That is, if an individual is interested in his work, he has a sense of belonging, but if he is uninterested and uninvolved, he is deprived of his sense of belonging. This uninterested occurring in the teaching profession may result in problems that are very difficult to solve among students who will graduate from schools to serve to educate future generations. The level of vocational belonging among teachers working in educational positions may positively or negatively affect how they teach and the relationships they have with students and other people.

In the study, a moderate positive correlation was found between job embeddedness and vocational belonging perceptions of the teachers. As the teachers' perceptions of job embeddedness increased, their perceptions of vocational belonging also increased. In other words, the teachers with a high level of perceptions of vocational belonging also had a high level of perceptions of job embeddedness. There are no studies in the literature that examine job embeddedness and vocational belonging perceptions of teachers. However, there are studies in the literature in which the relationship between job embeddedness and various other variables is examined. Lev and Koslowsky [40] analyzed the relationship between teachers' job embeddedness and their gender, organizational citizenship and organizational commitment. Lev and Koslowsky [65] examined the relationship between the job embeddedness of teachers and their sense of responsibility, job performance and contextual performance. Burke [41] analyzed the relationship between the job embeddedness of teachers and the support offered by the management or their colleagues. Mitchell [3] analyzed the relationship between job embeddedness and desire to quit the job, job satisfaction, organizational commitment and search for an alternative job. Lee, Mitchell, Sablynski, Burton and Holtom [9] analyzed the relationship between job embeddedness and organizational citizenship, job performance, intention to quit and conscious absenteeism. Sekiguchi et al. [21] analyzed the relationship between job embeddedness of an employee and his performance, interactive work leader-member 
exchange, organizational self-esteem and organizational citizenship behavior; $\mathrm{Ng}$ and Feldman [44] analyzed the relationship between job embeddedness and job performance. Birsel, Börü, İslamoğlu and Yurtkoru [8] analyzed the relationship between job embeddedness and socio-demographic variables Candan [42] analyzed the relationship between job embeddedness, job performance and burnout. Özçelik and Cenkci [45] analyzed the relationship between job embeddedness, patriarchal leadership and job performance. Şanlı [47] analyzed the relationship between job embeddedness and employee advocacy, organizational support and intention to quit the job. Nafei [46] analyzed the relationship between job embeddedness and organizational cynicism. Crossley, Bennett, Jex and Burnfield [19] and Şanlı [47] analyzed the relationship between the job embeddedness teachers and their intention to quit the job. Akgündüz, Güzel and Harman [61] analyzed the relationship between job embeddedness and trust in the manager. Kesen and Akyüz [62] analyzed the relationship between job embeddedness and prosocial motivation. Dedeoğlu et al. [63] analyzed the relationship between job embeddedness and the quality of work life, optimism and the quality of life. Kanten, Kanten and Dündar [60] analyzed the relationship between job embeddedness, happiness and satisfaction with the hierarchy of salary.

It has emerged from this research study that individuals who feel embedded in their jobs can develop commitment and a positive sense of belongingness towards their organizations. This is because being embedded in a job indicates a positive situation for individuals. If this positive situation can be used well, it can be thought that it is easier for teachers to identify with their institutions and to adapt to their institutions. This will help teachers to get rid of negative thoughts such as leaving their schools or quitting their jobs. It is also important that employees not only have certain qualifications, but also identify themselves with their professions and institutions and strive for the success of their institutions. This situation makes it necessary for employees to have a high level of vocational belonging. Vocational belonging is the main influence that improves and sustains motivation and performance in work life. In this respect, it has gained considerable importance in recent years for both employees and employers. The determination of the level of vocational belonging of individuals prevents the loss of qualified labor force as well as being a guide for creating solutions that will satisfy the parties and for developing innovations. Behaviors such as the following will increase both the job embeddedness and vocational belonging of teachers: Taking into account the suggestions, complaints and requests of employees; creating a comfortable and peaceful work environment for employees; being fair and effective in the decisions taken and including employees in the decision-making process; being transparent; ensuring trust; dealing with employees' organizational and individual problems and listening to them; allocating time; giving feedback on successes/failures; being at an equal distance to all of the employees without favoring any of them; and being able to show an approach from a humanist point of view.

Based on the results presented above, it can be argued that job embeddedness is quite a new field of study in Turkey. Therefore, the relationship between this concept and other concepts can be examined especially in educational settings. Teachers can review their level of job embeddedness and the factors that affect their adaptation to schools and to their environment. They can reconsider how establishing connections with the organization and the environment contributes to themselves. And, they can also review how sacrificing for the school and the environment will let them into an interaction with themselves, with their surroundings and with their organizations. They can spend more time at schools especially to improve their behaviors in a positive sense. Certain activities can be carried out in this respect, such as in-service trainings or similar activities related to communication and problem solving techniques to enhance positive emotions, thoughts and behaviors and to reduce negative ones. This study was designed to determine teachers' vocational belongings. Similar studies can be carried out on different sample groups such as inspectors, school administrators, students and parents. Moreover, studies on vocational belonging can be carried out in different types of schools such as secondary schools, high schools and universities.

\section{REFERENCES}

[1] Özyar,, A. (2003). Milli Eğitim Bakanlığı'nın öğretmen yetiştirme politikaları. (http://oyegm.meb.gov.tr/ortasayfa/ gn_md_sunu.htm]

[2] Seferoğlu, S. S. (2003). Öğretmenlerin hizmet-içi eğitiminde yeni yaklaşımlar. Çağdaş Eğitim Sistemlerinde Öğretmen Yetiştirme Ulusal Sempozyumu, Eğitimde Yansımalar: VII, s. 149-167.

[3] Mitchell, T.R., Holtom, B.C., Lee, T.W., Sablynski, C.J., ve Erez, M. (2001). Why people stay: using job embeddedness to predict voluntary turnover. Academy of Management Journal, 44(6), 1102-1121.

[4] Ringl, R. W. (2013). The Relationship between Job Embeddedness and Work Engagement .Master's Theses. San Jose State University, SJSU ScholarWorks 4361. http://scholarworks.sjsu.edu/etd_theses/4361

[5] Kıran, E. (2017). Örgütsel sinizm ve işe gömülü olmanın psikolojik sermaye ile işten ayrılma niyeti arasındaki ilişkideki aracılık rolü: kamu çalışanları üzerine bir araştırma. Yayınlanmamış Yüksek Lisans Tezi, Mustafa Kemal Üniversitesi, Sosyal Bilimler Enstitüsü, Hatay.

[6] Holtom, B.C., Mitchell, T.R. and Lee, T.W., (2006). Increasing human and social capital by applying job embeddedness theory. Organizational Dynamics, 35(4), 


\section{6-331. doi:10.1016/j.orgdyn.2006.08.007}

[7] Mallol, C.M., Holtom, B.C. and Lee, T.W. (2007). Job embeddedness in a culturally diverse environment. Journal of Business and Psychology, 22(1), 35-44. doi:10.1007/s10869-007-9045-x

[8] Birsel, M., Börü, D., İslamoğlu, G. and Yurtkoru, E.S. (2012). Job embeddedness in relation with different socio demographic characteristics. Öneri, 10(37), 51-61.

[9] Lee, T.W., Mitchell, T.R., Sablynski, C.J., Burton, J.P. and Holtom, B.C. (2004). The effects of job embeddedness on organizational citizenship, job performance, volitional absences, and voluntary turnover. Academy of Management Journal, 47(5), 711-722.

[10] Holtom, B.C. and Inderrieden, E.J. (2006). Integrating the unfolding model and job embeddedness model to better understand voluntary turnover. Journal of Managerial Issues, 17(4), 435-452.

[11] Karatepe, O.M. (2012). The effects of coworker and perceived organizational support on hotel employee outcomes: The moderating role of job embeddedness. Journal of Hospitality \& Tourism Research, 36(4), 495-516.

[12] Oyler, J. D. (2007). Oyler, J. D. (2007). Core Self-Evaluations and Job Satisfaction: The Role of Organizational and Community Embeddedness. Faculty of Virginia Polytechnic Institute and State University. Unpublished Doctoral Dissertation.

[13] Allen, D.G. (2006). Do organisational socialisation tactics influence newcomer embeddedness and turnover? Journal of Management, 32(2), 237-256. http:// dx.doi.org/10.1177/0149206305280103.

[14] Hom, P. W., and Hulin, C. L. (1981). A competitive test of the prediction of reenlistment by several models. Journal of Applied Psychology, 66(1), 23.

[15] Prestholdt, P. H., Lane, I. M., and Mathews, R. C. (1987). Nurse turnover as reasoned action: Development of a process model. Journal of Applied Psychology, 72(2), 221.

[16] Price, J. L., and Mueller, C. W. (1981). A causal model of turnover for nurses. Academy of management journal, 24(3), 543-565.

[17] Turban, D. B., Campion, J. E., and Eyring, A. R. (1992). Factors relating to relocation decisions of research and development employees. Journal of Vocational Behavior, 41, 183-199.

[18] Bambacas, M. and Kulik, T. C. (2013). Job embeddedness in China: how HR practices impact turnover intentions. The International Journal of Human Resource Management, 24(10), 1933-1952, DOI:10.1080/09585192.2012.725074.

[19] Crossley, C.D., Bennett, R.J., Jex, S.M. and Burnfield, J.L. (2007). Development of a global measure of job embeddedness and integration into a traditional model of voluntary turnover. Journal of Applied Psychology, 92(2), $1031-1042$

[20] Burton, J. P. (2014). The role of job embeddedness in the relationship between bullying and aggression, European Journal of Work and Organizational Psychology, DOI: 10.1080/1359432X.2014.944169.
[21] Sekiguchi, T., Burton, J.P. and Sablynski, C., H. (2008). The role of job embeddedness on employee performance: The Interactive effects with leader-member exchange and organization-based self-esteem. Personnel Psychology, 61, 761-792

[22] Uzzi, B. (1999) Embeddedness in the making of financial capital: how social relations and networks benefit firms seeking financing. American Sociological Review, 64(4), 481-505.

[23] Hagerty, B., and Patusky, K. (1995). Developing a measure of sense of belonging. Nursing Research, 44, 9-13.

[24] Keskin, S. and Seferoğlu, S.S. (2017) An investigation of prospective teachers' sense of belonging and perceptions of the community of inquiry. Mehmet Akif Ersoy University Journal of Faculty of Education, 44, 90-114

[25] Keskin, R. and Pakdemirli, M.N. (2016). Vocational belonging scale: a study of developing a valid and reliable scale. The Journal of International Social Research, 9(43), 2580-2587

[26] Alptekin, D. (2012). Toplumsal Aidiyet ve Gençlik, Ankara: Nobel Yayınları.

[27] Şimşek, Ş. (1999). Yönetim ve organizasyon. İstanbul: Danışman Yayınları.

[28] Erdoğan, İ., (1996). İşletme Yönetiminde Örgütsel Davranış. İstanbul: Avcı Basımevi.

[29] Morrow, P. C. (1983). Concept redundancy in organizational research: The case of work commitment. The Academy of Management Review, 8 (3), 486-500.

[30] Aranya, N., Pollock, J. and Amernic, J. (1981). An examination of Professional commitment in public accounting. Accounting, Organizations and Society, 6 (4), 271-280.

[31] Yeşilçelebi, G. (2014). Mesleki aidiyetin bağımsız denetim kalitesi üzerine etkisi: bağımsız denetçiler üzerine bir araştırma. Yayınlanmış Yüksek Lisans Tezi. Anadolu Üniversitesi Sosyal Bilimler Enstitüsü, Eskişehir.

[32] Gören, T. and Sarpkaya, P. Y (2014). The level of organizational commitment of the teachers in primary schools in Aydin. Journal of Educational Sciences, 40, 69-87.

[33] İlhan, S. (2008). On the New Capitalism and the Changing Meanings of the Occupation Phenomenon. Dumlupinar University Journal of Social Sciences, 21, 313-328.

[34] Karaca, S. (2001). İş Tatmininin Örgütsel Bağlılık Üzerindeki Etkisi ve Bir Uygulama. Yayımlanmıs Yüksek Lisans Tezi, Atatürk Üniversitesi Sosyal Bilimler Enstitüsü, Erzurum.

[35] Ekinci, H. and Ekici S., (2003). İşletmelerde Örgütsel Stres Yönetim Stratejisi Olarak Sosyal Desteğin Rolüne İlişkin Görgül Bir Araștırma. Cumhuriyet Üniversitesi Sosyal Bilimler Dergisi, 27, 1.

[36] Özdevecioğlu, M. and Aktaş, A. (2007). The effects of career commitment, occupational commitment and organizational commitment on life satisfaction: the role of work-family conflict. Erciyes Unıversity Journal of Faculty of Economics and Administrative Sciences, 28, 1-20. 
[37] Tella, A.; Ayeni, C. O. and Popoola, S. O. (2007). Work motivation, job satisfaction, and organisational commitment of library personnel in academic and research libraries in Oyo State, Nigeria. Library hilosophy and Practice, 1-16.

[38] Elias, R. Z. (2006). The impact of professional commitment and anticipatory socialization on accounting students' ethical orientation. Journal of Business Ethics, 68, 83-90.

[39] Greenfield, A. C. Norman, C. S. and Wier, B. (2008). The effect of ethical orientation and professional commitment on earnings management behavior. Journal of Business Ethics, 83, 419-434.

[40] Lev, S. and Koslowsky, M. (2012a). On-the-job embeddedness as a mediator between conscientiousness and school teachers' contextual performance. European Journal of Work and Organizational Psychology, 21(1), 57-83. doi.org/10.1080/1359432X.2010.535656

[41] Burke, A.M. (2015). The role of job embeddedness in special education teacher retention. Unpublished Doctoral Dissertation, Arizona: Northcentral University.

[42] Candan, H. (2016). Türkiye'de akademisyenlerin işe gömülmüşlükleri ile performans ve tükenmişlikleri arasındaki ilişkinin incelenmesine yönelik bir araştırma. IOSR Journal of Business and Management, 18(3), 68-80.

[43] Nafei, W.A. (2015a). The role of psychological capital on job embeddedness and organizational cynicism: a study on menoufia university hospitals. Journal of Business Administration, 5(1), 50-74. doi:10.5430/ijba.v6n1p8

[44] Ng, T.W.H. and Feldman, D.C. (2009). Occupational Embeddedness and Job Performance. Journal of Organizational Behavior, 30(7), 863-891. doi:10.1002/job. 580

[45] Özçelik, G. and Cenkci, T. (2014). Moderating effects of job embeddedness on the relationship between paternalistic leadership and in-role job performance. 10th International Strategic Management Conference, Procedia-Social and Behavioral Sciences, $\quad 150, \quad 872-880$. doi:10.1016/j.sbspro.2014.09.096

[46] Nafei, W.A. (2015b). The effects of job embeddedness on organizational cynicism and employee performance: A study on sadat City University. International Journal of Management and Sustainability, 6(1), 8-25. doi:10.5539/jms.v5n1p50

[47] [Şanlı, S. (2016). İşgören avukatlığı ve algılanan örgütsel desteğin çalışanların işe gömülmüşlük ve işten ayrılma niyeti üzerine etkisi: otel çalışanları üzerine bir araştırma. Yayınlanmamış Yükseklisans Tezi, Mersin: Mersin Üniversitesi.

[48] Duru, E. and Balkıs, M. (2015). Birey-çevre uyumu, aidiyet duygusu, akademik doyum ve akademik başarı arasındaki ilişkilerin analizi. Ege Eğitim Dergisi, 16 (1), 122-141.

[49] Öztaş, S. (2010). Kadrolu, sözleşmeli ve ücretli statüye göre öğretmenlerin mesleki aidiyet duygusunun değerlendirilmesi. Yayınlanmamış Yüksek Lisans Tezi. Gazi Üniversitesi, Eğitim Bilimleri Enstitüsü, Ankara.

[50] Sar1, M. (2013). Sense of school belonging among high school students. Anadolu University Journal of Social
Sciences. 13(1), 147-160.

[51] Özgök, A. (2013). Ortaokul Öğrencilerinde Okula Aidiyet Duygusunun Arkadaşlara Bağl1lık Düzeyinin ve Empatik Sınıf Atmosferi Algısının İncelenmesi. Yayımlanmamıs Yüksek Lisans Tezi. Çukurova Üniversitesi Sosyal Bilimler Enstitüsü, Adana.

[52] Öztop, S. (2014). Influence of organizational sense of belonging on employees' perception of organizational change. Süleyman Demirel University The Journal of Faculty of Economics and Administrative Sciences, 19(1), s. 299-316.

[53] Şahin, F. (2013). Özel eğitim okullarında çalışan kadrolu, emekli ücretli ve ücretli öğretmenlerin mesleki aidiyet duygularının değerlendirilmesi. Yayınlanmamış Yüksek Lisans Tezi. Yeditepe Üniversitesi, Sosyal Bilimler Enstitüsü, İstanbul.

[54] Sünbül, A. M. (2001) Bir Meslek Olarak Öğretmenlik. Öğretmenlik Mesleğine Giriș. (Edit: Ö. Demirel-Z. Kaya) Ankara: Pegem Yayıncılık.

[55] Büyüköztürk, Ş., Çakmak, E., Akgün, Ö., Karadeniz, Ş., and Demirel, F., (2009). Bilimsel Araştırma Yöntemleri, Pegem Akademi, Ankara.

[56] Felps, W., Mitchell, T.R., Hekman, D.R., Lee, T.W., Holtom, B.C., and Harman, W.S. (2009). Turnover contagion: how coworkers' job embeddedness and job search behaviors influence quitting. Academy of Management Journal, 52(3), 545-561.

[57] Alpar, R. (2014). Spor sağlık ve eğitim bilimlerinden örneklerle uygulamalı istatistik ve geçerlik - güvenirlik (3. Baskı). Ankara: Detay Yayıncılık.

[58] Büyüköztürk, Ş., Çokluk, Ö. and Köklü, N. (2011). Sosyal bilimler için istatistik (7.bask1). Türkiye. Pegem.

[59] Perie, M. and Baker, D., P. (1997). Job satisfacton among America's teachers: Effects of workplace conditions, background characteristics and teachers compensation. Statistical analysis report. Web: http://www.eric.ed.gov /ERICWebPortal

/Home.portal? nfpb=true\&ERICExtSearch SearchValue $0=\mathrm{Job}+$ Satisfacton+Among+America $\% \mathrm{E} 2 \% 80 \% 99 \mathrm{~s}+\mathrm{Teac}$ hers $\% 3 \mathrm{~A}+$ Effects + of + Workplace + Conditions $\% 2 \mathrm{C}+$ Backg round+Characteristic $\mathrm{s}+$ and +Teachers+Compensation\&ERICExtSearch SearchType $0=$ kw\& pageLabel=ERICSearchResult\&new Search $=$ true $\&$ rnd $=1208463714004 \&$ searchtype $=$ basic

[60] Kanten, P., Kanten, S. and Gurlek, M. (2015). The effects of organizational structures and learning organization on job embeddedness and individual adaptive performance. 2nd Global Conference on Business, Economics, Management and Tourism (30-31 October), Prague, Czech Republic, Procedia Economics and Finance, 23(2015), 1358-1366

[61] Akgündüz, Y., Güzel, T. and Harman, S. (2016). How the Manager Trust and Distributive Justice Can Affect the Employees' Job Embeddedness? Ege Academic Review, 16(2), 351-362

[62] Kesen, M. and Akyüz B. (2016). The impact of emotional labour and prosocial motivation on job embeddedness: a field research on health sector employees. Çukurova University Journal of Social Sciences, 25(2), 233-250. 
[63] Dedeoğlu, T., Özdevecioğlu, M., and Oflazer, S.( 2016). Örgütlerde işe gömülmüşlüğün (job embededness) çalışanların iş ve yaşam kalitesi üzerindeki etkisi: iyimserliğin rolü (the effect of job embededness on employees quality of work life and quality of life: the role of optimism). Erciyes Üniversitesi İktisadi ve İdari Bilimler Fakültesi Dergisi, 47, 135-146.

[64] Lord, A. T. and DeZoort, F. T. (2001). The impact of commitment and moral reasoning on auditors' responses to social influence pressure. Accounting, Organizations and
Society, 26, 215-235.

[65] Lev, S. and Koslowsky, M. (2012b) Teacher gender as a moderator of the on the job embeddedness-ocb relationship. Journal of Applied Social Psychology, 42(1), 81-99.

[66] Erdoğan, S. (2006). Yeni yönetim anlayışı açısından aidiyet duygusu ve hizmet sektöründe bir uygulama. Yayınlanmış Yüksek Lisans Tezi. Uludağ Üniversitesi Sosyal Bilimler Enstitüsü, Bursa. 